\title{
Antimalarial drug use in general populations of tropical Africa
} Florence Gardella1,2, Serge Assi ${ }^{3}$, Fabrice Simon ${ }^{4}$, Hervé Bogreau ${ }^{1,2}$, Teunis Eggelte ${ }^{5}$, Fatou $\mathrm{Ba}^{6}$, Vincent Foumane ${ }^{7}$, Marie-Claire Henry ${ }^{8}$, Pélagie Traore Kientega ${ }^{8}$, Léonardo Basco ${ }^{7}$, Jean-François Trape ${ }^{6,2}$, Richard Lalou ${ }^{9}$, Maryse Martelloni10, Marc Desbordes ${ }^{10}$, Meïli Baragatti1,2, Sébastien Briolant ${ }^{1,2}$, Lionel Almeras ${ }^{1,2}$, Bruno Pradines ${ }^{1,2}$, Thierry Fusai ${ }^{1,2}$ and Christophe Rogier*1,2

\author{
Address: ${ }^{1}$ Unité de Recherche en Biologie et Epidémiologie Parasitaires (URBEP), IMTSSA, Parc du Pharo - B.P. 46, 13998, Marseille-Armées, \\ France, ${ }^{2}$ Unité de recherche sur les Maladies Infectieuses et Tropicales Emergentes (URMITE) - UMR 6236, Faculté de Médecine, 27 Bv Jean \\ Moulin, 13385, Marseille, Cedex 05, France, ${ }^{3}$ Institut Pierre Richet/Institut National de Santé Publique, BP V 47, Abidjan, Cote d'Ivoire, ${ }^{4}$ Hôpital \\ Laveran, BP 50, 13998, Marseille-Armées, France, ${ }^{5}$ Dept. Infectious Diseases, AIDS and Tropical Medicine, Dep Clinical Pharmacology \\ Meibergdreeef 15, 1105 AX, Amsterdam, The Netherlands, ${ }^{6}$ UR 077 Paludologie Afrotropicale, BP1386, IRD, Dakar, Sénégal, 7 UR 077 Paludologie \\ Afro-Tropicale, OCEAC, BP 288, Yaoundé, Cameroun, ${ }^{8}$ Centre Muraz, BP 360, Bobo-Dioulasso, Burkina-Faso, ${ }^{9}$ LPED, Université de provence, case \\ 10, 3, place Victor-Hugo, 13331, Marseille, cedex 3, France and ${ }^{10}$ Unité de Recherche en Pharmacologie et Physiopathologie Parasitaires, IMTSSA, \\ Parc du Pharo - B.P. 46, 13998, Marseille-Armées, France \\ Email: Florence Gardella - gardella_f@yahoo.fr; Serge Assi - assisergi@yahoo.fr; Fabrice Simon - simon-f@wanadoo.fr; \\ Hervé Bogreau - hervebogreau@yahoo.fr; Teunis Eggelte - t.a.eggelte@amc.uva.nl; Fatou Ba - fall1fatou@yahoo.fr; \\ Vincent Foumane - vfoumane@yahoo.fr; Marie-Claire Henry - marie-claire.henry@ird.fr; Pélagie Traore Kientega - pkwpelagie@yahoo.fr; \\ Léonardo Basco - lkbasco@yahoo.fr; Jean-François Trape - trape@ird.fr; Richard Lalou - lalou@up.univ-mrs.fr; \\ Maryse Martelloni - maryse.martelloni@laposte.net; Marc Desbordes - marc_desbordes@hotmail.com; \\ Meïli Baragatti - baragattimeili@hotmail.com; Sébastien Briolant - sbriolant@wanadoo.fr; Lionel Almeras - l.almeras@wanadoo.fr; \\ Bruno Pradines - bruno.pradines@free.fr; Thierry Fusai - thierry.fusai@free.fr; Christophe Rogier* - christophe.rogier@wanadoo.fr \\ * Corresponding author
}

Published: 8 July 2008

Malaria Journal 2008, 7:124 doi:10.1 I86/1475-2875-7-124
Received: 14 January 2008

Accepted: 8 July 2008

This article is available from: http://www.malariajournal.com/content/7/I// 24

(C) 2008 Gardella et al; licensee BioMed Central Ltd.

This is an Open Access article distributed under the terms of the Creative Commons Attribution License (http://creativecommons.org/licenses/by/2.0), which permits unrestricted use, distribution, and reproduction in any medium, provided the original work is properly cited.

\begin{abstract}
Background: The burden of Plasmodium falciparum malaria has worsened because of the emergence of chloroquine resistance. Antimalarial drug use and drug pressure are critical factors contributing to the selection and spread of resistance. The present study explores the geographical, socio-economic and behavioural factors associated with the use of antimalarial drugs in Africa.
\end{abstract}

Methods: The presence of chloroquine (CQ), pyrimethamine (PYR) and other antimalarial drugs has been evaluated by immuno-capture and high-performance liquid chromatography in the urine samples of 3,052 children (2-9 y), randomly drawn in 2003 from the general populations at 30 sites in Senegal (I0), Burkina-Faso (10) and Cameroon (10). Questionnaires have been administered to the parents of sampled children and to a random sample of households in each site. The presence of $\mathrm{CQ}$ in urine was analysed as dependent variable according to individual and site characteristics using a random - effect logistic regression model to take into account the interdependency of observations made within the same site.

Results: According to the sites, the prevalence rates of CQ and PYR ranged from $9 \%$ to $91 \%$ and from $0 \%$ to $21 \%$, respectively. In multivariate analysis, the presence of $C Q$ in urine was significantly 
associated with a history of fever during the three days preceding urine sampling $(O R=1.22, p=$ $0.043)$, socio-economic level of the population of the sites $(O R=2.74, p=0.029)$, age $(2-5 y=$ reference level; 6-9 y OR $=0.76, p=0.002$ ), prevalence of anti-circumsporozoite protein (CSP) antibodies (low prevalence: reference level; intermediate level $O R=2.47, p=0.023$ ), proportion of inhabitants who lived in another site one year before $(O R=2.53, p=0.003)$, and duration to reach the nearest tarmacked road (duration less than one hour $=$ reference level, duration equal to or more than one hour $O R=0.49, p=0.019)$.

Conclusion: Antimalarial drug pressure varied considerably from one site to another. It was significantly higher in areas with intermediate malaria transmission level and in the most accessible sites. Thus, P. falciparum strains arriving in cross-road sites or in areas with intermediate malaria transmission are exposed to higher drug pressure, which could favour the selection and the spread of drug resistance.

\section{Background}

Malaria remains a major public health problem in Africa. Around $60 \%$ of 250-500 million clinical disease episodes and over $80 \%$ of 1.25 million deaths attributed each year to malaria occur in sub-Saharan Africa [1]. Several studies have described a two-fold increase in deaths due to malaria during the 1980s and 1990s because of the emergence of the chloroquine resistance [2-4]. However recent publications have documented a decline in malaria morbidity and mortality trends attributed to the increased access to artemisinin-based combination therapies and widespread use of insecticide-treated nets [5-7].

Drug pressure, intensity of malaria transmission and population movement favour the spread of antimalarial drug resistance [8-10]. Uncontrolled antimalarial drug use is a critical factor that contributes to the drug pressure. Exploring socio-cultural factors which influence antimalarial drug use has been recognized as a priority. Furthermore, since one of the objectives of Roll Back Malaria was to promote an equitable coverage and access of antimalarial drugs [11], the impact of environmental and behavioural factors on treatment use is important to be recognized. However, few studies have focused on this aspect of the epidemiology of drug-resistant malaria $[12,13]$. The distance to public health facilities, socio-economic level, age and parasite prevalence have been identified as key factors of drug use, but these factors have been described generally without taking into account each other simultaneously. Thus, the possible associations and interactions of these factors have never been explored. In order to evaluate the association between the use of antimalarial drug and geographical, socio-economic and behavioral factors, a multi center cross-sectional study was conducted in 2003 in 30 sites from three countries (Senegal, Burkina Faso and Cameroon), when $\mathrm{CQ}$ was still the first-line treatment of uncomplicated malaria. Although the sites are not formally representatives of the whole continent, they represent a wide panel of ecosystems and malaria endemicity conditions.

\section{Methods \\ Study sites}

The study was conducted in two regions (in the north and the south of each country) in Senegal (sites \#1 to 10), Burkina-Faso (sites \#11 to 20) and Cameroon (sites \#21 to 30) (Figure 1), between September 30 and December 17,2003 . In each area, this period corresponded to the end of the malaria transmission season or during the low transmission season. The rainy season (i.e. with an average of five or more rainy days per month in the nearest locality referred at http://www.meteofrance.com/FR/cli mat/clim afriq.jsp\#) lasts from August to September, from June to October, from May to September, from May to October and from May to October, in north Senegal, south Senegal, north Burkina-Faso, south Burkina-Faso and north Cameroon, respectively. In south Cameroon, there are two rainy seasons from March to June and from September to November. A list of different possible combinations of five sites (districts of towns or villages) was established for each region. The combinations were made to maximize the differences in environmental conditions suitable for malaria transmission, access to health structures and transport facilities between sites. A combination of five sites was randomly selected from the list of each region. In Burkina Faso, the combination of sites included three sites in an urban area and two sites in a rural area. In the regions of the other countries, only rural sites were included.

The informed consent of the parents of each child was obtained orally at the beginning of the study after a thorough explanation of its purpose. The study design received clearance from the Senegal (Dakar), Burkina Faso (Ouagadougou) and Cameroon (Yaoundé) National Ethics Committees.

\section{Site characteristics}

In each site, 30 households were randomly selected from a numbered households list when it was available for the site or using a random-walk that was calibrated to be able 


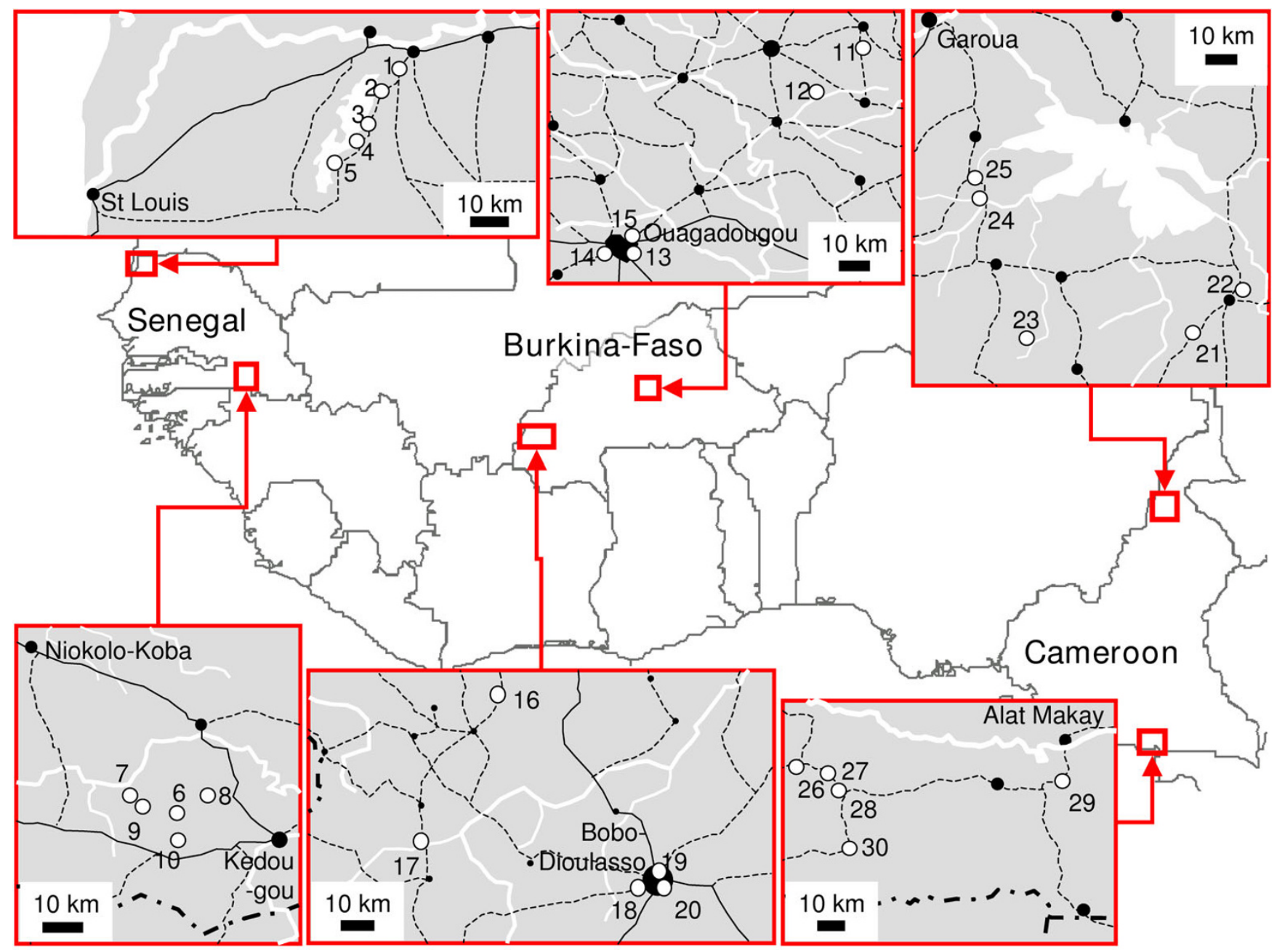

Figure I

Map of the study areas in West and Central Africa. Study sites are indicated by open discs and their ID numbers on the maps of the study areas. Hydrographic networks are in white. Road networks are in black. Main localities are indicated by filled discs.

to cover the whole of the surface of the site and started from its center.

The head of each household was interviewed on the number of individuals in the household, the number of rooms occupied, and the presence of the following facilities: running water, electricity, kitchen, refrigerator, living room, dining room, television, radio, video recorder, mobile, landline phone, vehicle, characteristics of the house (wall without anfractuosities, ground built with tiles or cement, windows that can be closed hermetically, roof built with a permanent structure). The number of these facilities that were present was calculated and used as an unweighted score from 0 to 16 reflecting the socioeconomic level of each household.
A numbered list of all the inhabitants was drawn up for each household. Among them, up to three individuals were randomly chosen using a random numbers table. These individuals or their legal tutor were interviewed on their history of previous malaria attack, their personal characteristics (including age, last travel outside his/her village or town, length of residence in the site), their travels (number of nights spent in another village in the last 30 days) and their use of antimalarial drugs (including names of anti-malarial drugs commonly used, places where drugs are purchased, presence of stocks of medicines in the household). The sites were characterized by aggregating data collected from individuals or households (by calculating the median or proportion). Distances between sites and towns, sanitary structures and transport 
system were obtained from global positioning system coordinates. The duration of the corresponding travel were estimated by the averaged responses from key persons and heads of households.

\section{People}

The consumption of antimalarial drug was estimated by testing the presence of chloroquine (CQ) and pyrimethamine (Pyr) parent compounds and metabolites in urine samples of 100 children between two and nine years of age randomly selected in each site, independently of their clinical status. Parental consent was obtained for each child. The test is based on an enzyme-linked immunosorbent assay (ELISA) blocking test, where immobilized antibody was first reacted with the test sample and then with a drug-peroxidase-enzyme conjugate and finally with the peroxidase-enzyme-substrate [14]. The sensitivity for the detection of CQ and Pyr were $20 \mathrm{ng} / \mathrm{ml}$ and $50 \mathrm{ng} / \mathrm{ml}$, respectively. The specificity in negative controls was $100 \%$. The presence of antimalarials in urine was also tested in a random sub-sample of urine from each country using an high-performance liquid chromatography (HPLC) technique. A numbered list of all the urines was drawn up for each country. Among them, up to hundred urine samples were randomly chosen using computergenerated random numbers and sent at $-20^{\circ} \mathrm{C}$ to France and then kept at $-80^{\circ} \mathrm{C}$ until analysis. Samples without sufficient volume of urines (e.g. that were spilt during the transport) were not processed. HPLC allows the detection of CQ (the sensitivity has been defined for each molecule), amodiaquine, quinine, mefloquine, halofantrine, proguanil, sulphadoxine, doxycycline and pyrimethamine, as described elsewhere $[15,16]$.

Fingerprick capillary blood was obtained to prepare Giemsa-stained thick smears. Parasite density and the number of trophozoites against 100 leukocytes were calculated for each Plasmodium species. Blood spots were collected and dried on Whatman ${ }^{\circledR} 3 \mathrm{MM}$ filter paper. IgG antibody against $P$. falciparum circumsporozoite protein (CSP) was measured in dried blood samples using elution and ELISA techniques described elsewhere $[17,18]$. Sites were classified according the prevalence of anti-CSP antibodies: low (less than 20\%), intermediate (20 - <40\%) and high $(\geq 40 \%)$.

For each child, information on site, age, sex, clinical status (fever during the last three days), consumption of antimalarial drugs during the last seven days, travel during the last month was collected by questionnaires.

\section{Statistical methods}

Data were entered using EpiDATA v3.0 [19] and checked for consistency before statistical analysis using $\mathrm{R}$ 2.5.0. Descriptive analysis was done to determine the level of use of CQ and PYR, of anti-CSP antibodies, malaria or parasite rate and other characteristics by site.

The presence of CQ in urine was analysed as a dependent variable according to individual and site characteristics using a random-effect logistic regression model to take into account the interdependency of observations made within the same site.

A bivariate analysis was first performed by entering each independent variable in the logistic model. Variables were retained for the multivariate analysis when their effects had a p-value lower than 0.25. A multivariate analysis was done in two steps. First, an empty regression model was developed to evaluate the between-sites random variation. This was followed by the selection of children and site characteristics in the bivariate analysis and added to the model. Then a multivariate analysis was performed by a backward step-by-step procedure. The independent variables and their interactions were retained in the model if their effects were significant (likelihood ratio statistic, $\mathrm{p}<$ 0.05). The adequacy of the final model was estimated by the area under the receiver operating characteristic (ROC) curve and by looking at the adequacy between observed and predicted probabilities of detecting CQ in children's urine samples in each site.

\section{Results \\ Site description}

In the 30 sites, 3,231 children between two and nine years of age and 3,097 individuals from 1,109 households were randomly selected (Table 1 ). The prevalence of $P$. falciparum trophozoites was significantly $(\mathrm{p}<0.05)$ different between sites. It varied from $16.2 \%$ (site 2 ) to $96.1 \%$ (site 18 ) (Table 2), with a median of $72 \%$. It was significantly higher in the south than in the north of Senegal (72\% versus 25\%, p $\left.<10^{-3}\right)$, Burkina Faso (79\% versus 64\%, $\mathrm{p}<10^{-}$ 3 ), and Cameroon (78\% versus $61 \%, \mathrm{p}<10^{-3}$ ), and also higher in rural than in urban areas of Burkina Faso $(84 \%$ versus $\left.64 \%, \mathrm{p}<10^{-3}\right)$. It was higher among children older than five years than among children below five years of age $(65 \%$ versus $59 \%, \mathrm{p}=0.002)$.

The prevalence of anti-CSP-antibodies varied from $9.5 \%$ (sites 2 and 4 ) to $96.1 \%$ (site 12) (Table 2) according to sites, with a median of $31 \%$. It was significantly higher in the south than in the north in Senegal (54\% versus $14 \%$, $\left.\mathrm{p}<10^{-3}\right)$ and in Burkina Faso (70\% versus $\left.49 \%, \mathrm{p}<10^{-3}\right)$. In Cameroon, it was lower in the south (25\% versus $32 \%$ $\left.\mathrm{p}<10^{-3}\right)$. It was significantly higher in rural than in urban areas of Burkina Faso ( $86 \%$ versus $44 \%, \mathrm{p}<10^{-3}$ ) and higher among children aged more than five years old than among children aged less than five years (48\% versus $\left.32 \%, \mathrm{p}<10^{-3}\right)$. 
Table I: Study sites. ID number, country, region, type of area and geographical coordinates.

\begin{tabular}{|c|c|c|c|c|c|c|}
\hline Site's name & ID & Country & Region & $\begin{array}{l}\text { type of } \\
\text { area }\end{array}$ & $\begin{array}{c}\text { Latitude } \\
\text { degree }\end{array}$ & $\begin{array}{c}\text { Longitude } \\
\text { degree }\end{array}$ \\
\hline THIAGO & I & Senegal & North & rural & 16.4 & -15.72 \\
\hline TEMEYE SALANE & 2 & Senegal & North & rural & 16.33 & -15.77 \\
\hline SANINTE & 3 & Senegal & North & rural & 16.23 & -15.8 \\
\hline NDIAKHAYE & 4 & Senegal & North & rural & 16.18 & -15.82 \\
\hline MALLA & 5 & Senegal & North & rural & 16.12 & -15.87 \\
\hline TIABEDJI & 6 & Senegal & South & rural & 12.63 & -12.4 \\
\hline SAMAL & 7 & Senegal & South & rural & 12.67 & -12.5 \\
\hline THIOBO BANTATA & 8 & Senegal & South & rural & 12.67 & -12.33 \\
\hline ASSONI & 9 & Senegal & South & rural & 12.65 & -12.49 \\
\hline LANDE RUNDE. LANDE BAITIL & 10 & Senegal & South & rural & 12.55 & -12.40 \\
\hline TIPTENGA & 11 & Burkina Faso & North & rural & 13.09 & -0.81 \\
\hline FATIN & 12 & Burkina Faso & North & rural & 12.93 & -0.95 \\
\hline OUAGADOUGOU S29-30 & 13 & Burkina Faso & North & urban & 12.35 & -1.47 \\
\hline OUAGADOUGOU PISSY SI7 & 14 & Burkina Faso & North & urban & 12.34 & -1.56 \\
\hline OUAGADOUGOU NIOKO II S26 & 15 & Burkina Faso & North & urban & 12.42 & -1.47 \\
\hline NIENA & 16 & Burkina Faso & South & rural & 11.72 & -4.72 \\
\hline $\begin{array}{ll}\text { TENASSO }\end{array}$ & 17 & Burkina Faso & South & rural & 11.28 & -4.93 \\
\hline BOBO-DIOULASSO SAMAGAN & 18 & Burkina Faso & South & urban & 11.13 & -4.35 \\
\hline BOBO-DIOULASSO DOGONA & 19 & Burkina Faso & South & urban & 11.2 & -4.28 \\
\hline BOBO-DIOULASSO KUINIMA & 20 & Burkina Faso & South & urban & 11.15 & -4.28 \\
\hline YOUKOUT & 21 & Cameroon & North & rural & 8.29 & 14.09 \\
\hline TCHOLLIRE II & 22 & Cameroon & North & rural & 8.45 & 14.26 \\
\hline SAKDJE & 23 & Cameroon & North & rural & 8.27 & 13.65 \\
\hline BOCKI & 24 & Cameroon & North & rural & 8.75 & 13.53 \\
\hline KATE & 25 & Cameroon & North & rural & 8.78 & 13.52 \\
\hline MELEN/NKOLAFENDEK & 26 & Cameroon & South & rural & 2.77 & 12.52 \\
\hline MIATTA/DJOUZE & 27 & Cameroon & South & rural & 2.73 & 12.63 \\
\hline ENDEGUE/ABDELON & 28 & Cameroon & South & rural & 2.69 & 12.64 \\
\hline ZOEBEFAM/NKOLEMBOULA & 29 & Cameroon & South & rural & 2.72 & 13.34 \\
\hline YEN/MEBAN II & 30 & Cameroon & South & rural & 2.43 & 12.67 \\
\hline
\end{tabular}

The time necessary to join the nearest tarmacked road varied from 0 to 8.5 hours with a median of one hour. The proportion of inhabitants who lived in another site one year before the survey varied from $0 \%$ to $25 \%$ with a median of $4.3 \%$. The average index of the household socio-economic level varied from 0.9 to 8.7 with a median of 3. No systematic distribution of antimalarial drugs to the children had been organized in the sites during six previous months. The others sites characteristics (i.e. individual or household data aggregated by site) are presented in Additional Files 1 and 2.

\section{Chloroquine in urine}

CQ was tested in urine samples by dipstick in 3,052 of 3,231 children, aged 2-9 years (no urine was available for 179 children, i.e. $5 \%$ of the randomized children). Males represented $49.9 \%$ of the children for whom urine samples were available. The characteristics of the other children are detailed in Additional File 3. Among these 3,052 children, 41.4\% had CQ in their urine (1262/3052). The prevalence of CQ in children urine samples varied from $9.0 \%$ (site 7 ) to $90.1 \%$ (site 13 ) with a median of $32.2 \%$. The prevalence of CQ in urine was significantly different between countries (Senegal $=22 \%$, Burkina Faso $=47 \%$ and Cameroon $\left.=55 \%, \mathrm{p}<10^{-3}\right)$, between regions within the same country (i.e. higher in the north than in the south in Senegal [ $29 \%$ versus $14 \%, \mathrm{p}<10^{-3}$ ], in Burkina Faso, $\left[63 \%\right.$ versus $\left.31 \%, \mathrm{p}<10^{-3}\right]$, and in Cameroon, [ $66 \%$ versus $\left.44 \%, \mathrm{p}<10^{-3}\right]$ ]) and between sites from the same region (Table 2 ). It was significantly higher in urban than in rural areas of Burkina Faso (59\% versus 37\%, p = 0.047).

The prevalence of CQ in urine samples was higher in sites with a moderate prevalence rate of anti-CSP antibodies $(61 \%)$ than in sites with a low $(39 \%, \mathrm{p}<0.026)$ or high prevalence rate of anti-CSP antibodies $(23 \%, \mathrm{p}=0.088)$.

The prevalence of CQ in children's urine was higher in those aged $\leq 5$ years old than in children aged $>5$ years old $(49 \%$ versus $35 \%, \mathrm{p}=0.001)$. This difference was observed independently of the prevalence of anti-CSP antibodies in the sites (Figure 2).

The prevalence of CQ in urine was higher in children with a history of fever during the three days before urine sam- 
Table 2: Prevalence of Plasmodium falciparum trophozoites, anti-CSP antibodies and antimalarial drugs detected in children between two and nine years of age.

\begin{tabular}{|c|c|c|c|c|c|c|c|c|c|}
\hline \multirow[t]{3}{*}{ ID Site } & \multirow[t]{3}{*}{$\begin{array}{l}\text { Nb of thick } \\
\text { smears }\end{array}$} & \multirow{3}{*}{$\begin{array}{c}\begin{array}{c}\text { Prevalence of } \\
\text { trophozoites } \\
\text { (all species) }\end{array} \\
\begin{array}{c}\text { Nb of thick } \\
\text { smears }+ \\
(\%)\end{array}\end{array}$} & \multirow{3}{*}{$\begin{array}{c}\text { Prevalence of } \\
\text { Plasmodium } \\
\text { falciparum } \\
\text { trophozoites }\end{array}$} & \multicolumn{2}{|c|}{$\begin{array}{l}\text { Prevalence of anti-CSP } \\
\text { antibodies }\end{array}$} & \multicolumn{4}{|c|}{$\begin{array}{c}\text { Detection of antimalarial drugs in } \\
\text { children's urines }\end{array}$} \\
\hline & & & & $\mathrm{Nb}$ of & & \multicolumn{2}{|c|}{$\mathbf{C Q} \mathbf{Q}^{*}$} & \multicolumn{2}{|c|}{ PYR† } \\
\hline & & & & & & $\mathrm{CQ}+\ddagger$ & $\begin{array}{l}\text { Prevalence } \\
(95 \% \mathrm{Cl})\end{array}$ & $\mathrm{PYR}+\S$ & $\begin{array}{l}\text { Prevalence } \\
(95 \% \mathrm{Cl})\end{array}$ \\
\hline 1 & 100 & $26(26.0)$ & $25(25.0)$ & 100 & $13(13.0)$ & 36 & $\begin{array}{c}36.0 \\
(26.6-46.2)\end{array}$ & 0 & $\begin{array}{c}0.0 \\
(0.0-3.6)\end{array}$ \\
\hline 2 & 105 & $17(16.2)$ & $17(16.2)$ & 105 & $10(9.5)$ & 18 & $\begin{array}{c}18.0 \\
(11.0-26.9)\end{array}$ & 0 & $\begin{array}{c}0.0 \\
(0.0-3.6)\end{array}$ \\
\hline 3 & 111 & 21 (18.9) & $19(17.1)$ & 110 & $13(1 \mid .8)$ & 16 & $\begin{array}{c}14.5 \\
(8.5-22.5)\end{array}$ & 0 & $\begin{array}{c}0.0 \\
(0.0-3.3)\end{array}$ \\
\hline 4 & 120 & $23(19.2)$ & $22(18.3)$ & 118 & $12(10.2)$ & 56 & $\begin{array}{c}47.5 \\
(38.2-56.9)\end{array}$ & 0 & $\begin{array}{c}0.0 \\
(0.0-3.1)\end{array}$ \\
\hline 5 & 101 & $54(53.5)$ & $47(46.5)$ & 100 & $25(25.0)$ & 26 & $\begin{array}{c}25.7 \\
(17.6-35.4)\end{array}$ & 2 & $\begin{array}{c}2.0 \\
(0.2-7.0)\end{array}$ \\
\hline 6 & 100 & $79(79.0)$ & $72(72.0)$ & 100 & $55(55.0)$ & 20 & $\begin{array}{c}20.0 \\
(12.7-29.2)\end{array}$ & 0 & $\begin{array}{c}0.0 \\
(0.0-3.6)\end{array}$ \\
\hline 7 & 100 & $86(86.0)$ & $79(79.0)$ & 100 & $48(48.0)$ & 9 & $\begin{array}{c}9.0 \\
(4.2-16.4)\end{array}$ & 0 & $\begin{array}{c}0.0 \\
(0.0-3.6)\end{array}$ \\
\hline 8 & 103 & $89(86.4)$ & $83(80.6)$ & 103 & $75(72.8)$ & 14 & $\begin{array}{c}14.0 \\
(7.9-22.4)\end{array}$ & 0 & $\begin{array}{c}0.0 \\
(0.0-3.6)\end{array}$ \\
\hline 9 & 84 & 60 (7I.4) & 57 (67.9) & 84 & $39(46.4)$ & 18 & $\begin{array}{c}21.4 \\
(13.2-31.7)\end{array}$ & 0 & $\begin{array}{c}0.0 \\
(0.0-4.3)\end{array}$ \\
\hline 10 & 110 & 78 (70.9) & $66(60.0)$ & 110 & $51(46.4)$ & 10 & $\begin{array}{c}9.1 \\
(4.4-16.1)\end{array}$ & 0 & $\begin{array}{c}0.0 \\
(0.0-3.3)\end{array}$ \\
\hline 11 & 102 & $90(88.2)$ & $90(88.2)$ & 104 & $93(89.4)$ & 47 & $\begin{array}{c}46.1 \\
(36.2-56.2)\end{array}$ & 1 & $\begin{array}{c}1.0 \\
(0.0-5.3)\end{array}$ \\
\hline 12 & 102 & 93 (91.2) & $88(86.3)$ & 102 & $98(96.1)$ & 33 & $\begin{array}{c}33.7 \\
(24.4-43.9)\end{array}$ & 0 & $\begin{array}{c}0.0 \\
(0.0-3.7)\end{array}$ \\
\hline 13 & 102 & $4 I(40.2)$ & $4 I(40.2)$ & 104 & $21(20.2)$ & 98 & $\begin{array}{c}90.7 \\
(83.6-95.5)\end{array}$ & 1 & $\begin{array}{c}0.9 \\
(0.0-5.1)\end{array}$ \\
\hline 14 & 102 & $42(4 \mid .2)$ & $38(37.3)$ & 105 & $22(21.0)$ & 89 & $\begin{array}{c}80.2 \\
(71.5-87.1)\end{array}$ & 0 & $\begin{array}{c}0.0 \\
(0.0-3.3)\end{array}$ \\
\hline 15 & 100 & $69(69.0)$ & $68(68.0)$ & 101 & $24(23.8)$ & 60 & $\begin{array}{c}61.9 \\
(51.4-71.5)\end{array}$ & 0 & $\begin{array}{c}0.0 \\
(0.0-3.7)\end{array}$ \\
\hline 16 & 117 & $100(85.5)$ & 99 (84.6) & 115 & 82 (7I.3) & 18 & $\begin{array}{c}16.7 \\
(10.2-25.1)\end{array}$ & 0 & $\begin{array}{c}0.0 \\
(0.0-3.4)\end{array}$ \\
\hline 17 & 102 & 79 (77.5) & 78 (76.5) & 102 & $88(86.3)$ & 18 & $\begin{array}{c}20.0 \\
(12.3-29.8)\end{array}$ & 1 & $\begin{array}{c}1.1 \\
(0.0-6.0)\end{array}$ \\
\hline 18 & 102 & $98(96.1)$ & $98(96.1)$ & 105 & $93(88.6)$ & 18 & $\begin{array}{c}18.4 \\
(1 \mid .3-27.5)\end{array}$ & 0 & $\begin{array}{c}0.0 \\
(0.0-3.7)\end{array}$ \\
\hline 19 & 101 & $88(87.1)$ & $88(87.1)$ & 104 & $78(75.0)$ & 31 & $\begin{array}{c}31.3 \\
(22.4-4 \mid .4)\end{array}$ & 0 & $\begin{array}{c}0.0 \\
(0.0-3.7)\end{array}$ \\
\hline 20 & 104 & 55 (52.9) & $53(51.0)$ & 104 & $30(28.8)$ & 66 & $\begin{array}{c}68.8 \\
(58.5-77.8)\end{array}$ & 1 & $\begin{array}{c}1.0 \\
(0.0-5.7)\end{array}$ \\
\hline 21 & 101 & $65(64.4)$ & $55(54.5)$ & 99 & $23(23.2)$ & 49 & $\begin{array}{c}51.0 \\
(40.6-61.4)\end{array}$ & 20 & $\begin{array}{c}20.8 \\
(13.2-30.3)\end{array}$ \\
\hline 22 & 103 & $83(80.6)$ & 80 (77.7) & 66 & 25 (37.9) & 89 & $\begin{array}{c}89.0 \\
(81.2-94.4)\end{array}$ & 0 & $\begin{array}{c}0.0 \\
(0.0-3.6)\end{array}$ \\
\hline 23 & 101 & 79 (78.2) & 72 (7).3 & 99 & $46(46.5)$ & 35 & $\begin{array}{c}34.7 \\
(25.5-44.8)\end{array}$ & 1 & $\begin{array}{c}1.0 \\
(0.0-5.4)\end{array}$ \\
\hline 24 & 101 & $65(64.4)$ & $59(58.4)$ & 99 & $32(32.3)$ & 68 & $\begin{array}{c}67.3 \\
(57.3-76.3)\end{array}$ & 0 & $\begin{array}{c}0.0 \\
(0.0-3.6)\end{array}$ \\
\hline 25 & 100 & $52(52.0)$ & $4 \mid(4 \mid .0)$ & 86 & $16(18.6)$ & 91 & $\begin{array}{c}87.5 \\
(79.6-93.2)\end{array}$ & 0 & $\begin{array}{c}0.0 \\
(0.0-3.5)\end{array}$ \\
\hline
\end{tabular}


Table 2: Prevalence of Plasmodium falciparum trophozoites, anti-CSP antibodies and antimalarial drugs detected in children between two and nine years of age. (Continued)

\begin{tabular}{|c|c|c|c|c|c|c|c|c|c|}
\hline 26 & 101 & $86(85.1)$ & $74(73.3)$ & 102 & $29(28.4)$ & 56 & $\begin{array}{c}55.4 \\
(45.2-65.3)\end{array}$ & 0 & $\begin{array}{c}0.0 \\
(0.0-3.6)\end{array}$ \\
\hline 27 & 99 & $83(83.8)$ & 81 (8I.8) & 48 & $8(16.7)$ & 28 & $\begin{array}{c}27.2 \\
(18.9-36.8)\end{array}$ & 0 & $\begin{array}{c}0.0 \\
(0.0-3.5)\end{array}$ \\
\hline 28 & 104 & 87 (83.7) & $84(80.8)$ & 95 & $21(22.1)$ & 42 & $\begin{array}{c}39.6 \\
(30.3-49.6)\end{array}$ & 0 & $\begin{array}{c}0.0 \\
(0.0-3.4)\end{array}$ \\
\hline 29 & 103 & 81 (78.6) & $76(73.8)$ & 103 & $22(2 \mid .4)$ & 25 & $\begin{array}{c}24.3 \\
(16.4-33.7)\end{array}$ & 0 & $\begin{array}{c}0.0 \\
(0.0-3.5)\end{array}$ \\
\hline 30 & 107 & 91 (85.0) & $86(80.4)$ & 107 & $34(31.8)$ & 78 & $\begin{array}{c}72.9 \\
(63.4-81.0)\end{array}$ & 2 & $\begin{array}{c}1.9 \\
(0.2-6.6)\end{array}$ \\
\hline Total & 3088 & 2060 (66.7) & 1936 (62.7) & 2980 & $1226(4||)$. & 1262 & $\begin{array}{c}41.3 \\
(39.6-43.0)\end{array}$ & 29 & I (0.6-I.4) \\
\hline
\end{tabular}

$\mathrm{Nb}$ : number; \%, percent, *CQ: Chloroquine, † PYR: Pyrimethamine, $\ddagger \mathrm{CQ}+=$ number of samples with chloroquine in urine, §PYR+: number of samples with pyrimethamine in urine, Prevalence: expressed in percent.

pling than in children with no history of fever (51\% versus $38 \%, \mathrm{p}=0.032$ ), and in children who had traveled out of the site during the month before urine sampling than children who did not leave the site $(48 \%$ versus $41 \%, \mathrm{p}=$ 0.048).

The prevalence of CQ in urine was higher in sites with more than $5 \%$ of inhabitants living in another site one year before urine sampling ( $49 \%$ versus $33 \%, p=0.058$ ), in sites with an average socio-economic level equal to 6 or higher ( $68 \%$ versus $36 \%, \mathrm{p}=0.002$ ) and in sites in which the duration to join the nearest tarmacked road was less than one hour ( $48 \%$ versus $36 \%, p=0.206$ ). The other results of the bivariate analysis are presented in Tables 3 and 4 and in Additional File 4.

There was no significant interaction between variables retained in the model. In multivariate analysis, the prevalence of CQ in urine was lower among children above five years of age $(\mathrm{OR}=0.76,95 \% \mathrm{CI}=0.64-0.90)$, and in sites in which the duration to join the nearest tarmacked road

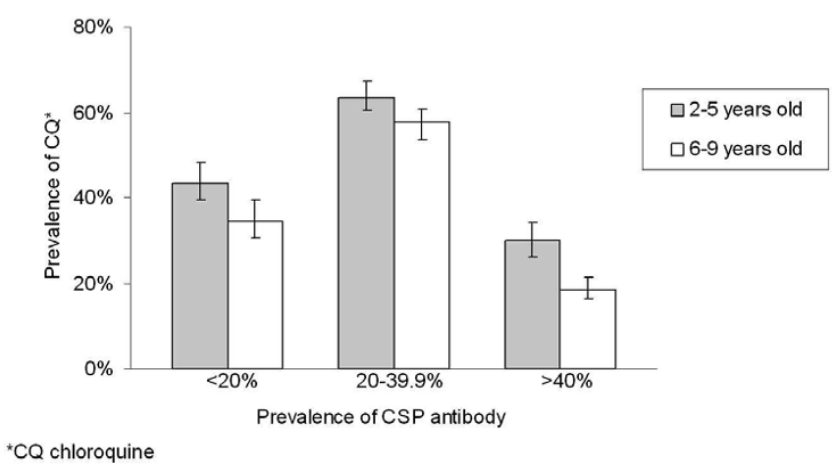

\section{Figure 2}

Prevalence rate (and $95 \%$ confidence interval) of chloroquine in urines of children between two and nine years of age according to their age and the prevalence rate of anti-CSP antibody among the children of the sites. *CQ: chloroquine. was one hour or more $(\mathrm{OR}=0.49,95 \% \mathrm{CI}=0.27-0.89)$. It was higher among children who declared a febrile episode during the three days preceding the urine sampling $(\mathrm{OR}=1.22,95 \% \mathrm{CI}=1.01-1.49)$, in sites with a high average socio-economical level $(\mathrm{OR}=2.74,95 \% \mathrm{CI}=$ 1.11-6.78), in sites with more than $5 \%$ of inhabitants living in another site one year before urine sampling $(\mathrm{OR}=$ $2.53,95 \% \mathrm{CI}=1.11-6.78)$ and in sites with a prevalence rate of anti-CSP antibodies among two to nine-year old children comprised between 20 and $39.9 \%(\mathrm{OR}=2.47$, $95 \% \mathrm{CI}=1.13-5.41$ ) (Table 5). The area under the ROC curve was 0.764 . Additional File 5 shows the adequacy between observed and expected prevalence of $\mathrm{CQ}$ in urine according to the final model.

\section{Pyrimethamine in urine}

PYR was tested using the same dipstick as CQ. The prevalence of PYR in children's urine samples varied from $0 \%$ to $21 \%$ (site 21 ) with a median of $0 \%$. It was $0.2 \%, 0.4 \%$ and $2.2 \%$ in Senegal, Burkina Faso and Cameroon, respectively. Because of the low prevalence rate of PYR in urine, no bivariate or multivariate analysis was done.

\section{Detection of antimalarials in urines using HPLC}

HPLC measurement of CQ was performed for 280 urine samples (i.e. 93, 98 and 89 children from Senegal, Burkina Faso and Cameroon, respectively). The prevalence of CQ detected by HPLC was $27 \%, 45 \%$ and $51 \%$ in Senegal, Burkina Faso and Cameroon, respectively. These prevalence rates were not significantly different from those estimated using dipsticks.

The prevalence of PYR detected by HPLC was $0 \%, 2 \%$ and $3 \%$ in Senegal, Burkina Faso and Cameroon, respectively. Amodiaquine was detected by HPLC in 6\% (16/280) of the urine samples. Its prevalence rate was $2 \%, 8 \%$ and $7 \%$ in Senegal, Burkina Faso and Cameroon, respectively. Quinine was detected by HPLC in $1 \%(3 / 280)$ of the urines. Its prevalence rate was $0 \%, 1 \%$ and $2 \%$ in Senegal, Burkina Faso and Cameroon, respectively. Mefloquine, 
Table 3: Chloroquine prevalence in urines of children between two and nine years of age according to children characteristics.

\begin{tabular}{|c|c|c|c|c|c|c|c|c|}
\hline \multicolumn{2}{|l|}{ Variables } & \multirow{2}{*}{\begin{tabular}{|l|}
$N^{*}$ \\
1524
\end{tabular}} & \multirow{2}{*}{$\frac{C Q+\dagger}{618}$} & \multirow{2}{*}{$\begin{array}{c}\begin{array}{c}\text { Prevalence of } \\
\text { presence of CQ } \ddagger \%\end{array} \\
4 I\end{array}$} & \multirow{2}{*}{$\begin{array}{c}\text { crude OR } \\
1.00\end{array}$} & \multicolumn{2}{|c|}{$95 \% \mathrm{Cl}$} & \multirow[t]{2}{*}{$\mathbf{p}$} \\
\hline Sex & Male & & & & & & & \\
\hline & Female & 1528 & 644 & 42 & 1.07 & 0.90 & 1.26 & 0.458 \\
\hline Age & $2-5$ years old & 1419 & 691 & 49 & 1.00 & & & \\
\hline & $6-9$ years old & 1633 & 571 & 35 & 0.74 & 0.63 & 0.89 & 0.001 \\
\hline Fever during the preceeding 3 days & without & 2252 & 852 & 38 & 1.00 & & & \\
\hline & with & 800 & 410 & 51 & 1.24 & 1.02 & 1.50 & 0.032 \\
\hline \multirow[t]{2}{*}{$\begin{array}{r}\text { Antimalarial treatment during the preceding } 7 \\
\text { days }\end{array}$} & no & 2652 & 995 & 38 & 1.00 & & & \\
\hline & yes & 400 & 267 & 67 & 1.90 & 1.46 & 2.47 & 0.000 \\
\hline \multirow[t]{2}{*}{ Travel during the preceding 30 days } & no & 2930 & 1203 & 41 & 1.00 & & & \\
\hline & yes & 122 & 59 & 48 & 1.52 & 1.00 & 2.30 & 0.048 \\
\hline \multirow[t]{2}{*}{ Malaria infection } & no & 974 & 466 & 48 & 1.00 & & & \\
\hline & yes & 1939 & 718 & 37 & 0.60 & 0.49 & 0.74 & 0.000 \\
\hline \multirow[t]{2}{*}{ Asexual Plasmodium falciparum infections } & no & 1094 & 518 & 47 & 1.00 & & & \\
\hline & yes & 1819 & 666 & 37 & 0.61 & 0.50 & 0.75 & 0.000 \\
\hline
\end{tabular}

$* \mathrm{~N}$ number of samples of urine, $\nmid \mathrm{CQ}+=$ number of samples with chloroquine in urines, $\ddagger \mathrm{CQ}$ : Chloroquine.

Logistic regression model with random effect taking into account the interdependency of observations made within the same site.

halofantrine, proguanil, sulphadoxine and doxycycline were not detected in any of the samples.

\section{Discussion}

CQ was the first-line antimalarial drug used in 2003 in Senegal, Burkina Faso and Cameroon among children between two and nine years of age. Other studies had shown that CQ was the main antimalarial drug used in Africa [20-22]. For example, in the study of Talusina et al conducted in 1998 and 1999 in Uganda, the prevalence of CQ in urine obtained from children between one and nine years of age was $48 \%$ [10]. According to the sites, CQ was present in $9 \%$ to $90 \%$ (median $32 \%$ ) of the urine samples collected in the present study. One of the significant findings of the study was the wide range of CQ prevalence observed from one site to another, including within the same region. Six factors associated with the heterogeneity of antimalarial drug use were identified.

\section{History of fever, age and socio-economic level}

Three of these factors were expected. The first expected factor was the history of fever in days preceeding urine sampling. In case of fever, parents usually administer antimalarial drugs to their children as a presumptive treatment [22-24]. Second, the prevalence of CQ in urine was lower among children older than five years, most of whom have acquired antimalarial immunity during the first five years of permanent residence in an endemic area $[25,26]$. This association between age and CQ consumption was observed independently of the anti-CSP antibodies prevalence rate, i.e. the level of malaria transmission. The third expected factor was the average socio-economic level. High socio-economic level is associated with the ability to seek health service. In the study by Biritwun et al
[27], conducted in Ghana, children from poorer community were less likely to take antimalarial treatment in a clinic or hospital as compared with children from a betteroff community. These three factors are similar to those identified in earlier studies on the treatment given for fever $[28,29]$.

\section{Population mobility}

Three less expected factors associated with CQ consumption have been identified in the present study. First, the prevalence of CQ in children's urine was higher in sites where the proportion of inhabitants living in another site one year ago was higher. Thus, drug pressure was highest in sites where population migration was most frequent. Second, the prevalence of CQ intake was higher in sites where the duration to join the nearest tarmacked road was shorter. Thus, drug pressure was highest in most accessible sites. It is possible that accessibility by tarmacked road facilitates access to health services, independently of the socio-economic level. These two factors indicate that population mobility in relation to migration and site accessibility is positively associated with a more frequent antimalarial drug use. Two consequences may be expected: i) probability of resistant $P$. falciparum strain imported from another region or country is higher, ii) selective drug pressure on the Plasmodium population is higher. It could have facilitated the diffusion of chloroquino-resistance $[8,30]$. It is the first time that antimalarial drug use is shown to be associated with population mobility.

\section{Malaria transmission}

The last factor associated with the presence of CQ in children's urine was the level of anti-CSP antibodies. The 
Table 4: Chloroquine prevalence in urines of children between two and nine years of age according to site's characteristics.

\begin{tabular}{|c|c|c|c|c|c|c|c|c|}
\hline \multicolumn{2}{|c|}{ Site's characteristics } & \multirow{2}{*}{$\begin{array}{l}\text { N* } \\
1023\end{array}$} & \multirow{2}{*}{$\frac{\text { CQ+† }}{223}$} & \multirow{2}{*}{$\begin{array}{c}\text { Prevalence of } \mathrm{CQ} \ddagger \text { \% } \\
22\end{array}$} & \multirow{2}{*}{$\begin{array}{c}\text { crudeOR } \\
1.00\end{array}$} & \multicolumn{2}{|c|}{$95 \% \mathrm{Cl}$} & \multirow[t]{2}{*}{$\mathbf{p}$} \\
\hline Country & Senegal & & & & & & & \\
\hline & Burkina Faso & 1007 & 478 & 47 & 3.69 & 1.49 & 9.16 & 0.005 \\
\hline & Cameroon & 1022 & 561 & 55 & 5.54 & 2.23 & 13.72 & 0.000 \\
\hline Region & North & 1547 & 811 & 52 & 1.00 & & & \\
\hline & South & 1505 & 451 & 30 & 0.31 & 0.15 & 0.66 & 0.002 \\
\hline Type of area & rural & 2443 & 900 & 37 & 1.00 & & & \\
\hline & urban & 609 & 362 & 59 & 2.93 & 1.01 & 8.46 & 0.047 \\
\hline \multirow[t]{2}{*}{$\begin{array}{r}\text { Prop. } \neq \text { living in an other locality one year before the } \\
\text { study }\end{array}$} & $<5 \%$ & 1424 & 471 & 33 & 1.00 & & & \\
\hline & $>=5 \%$ & 1628 & 791 & 49 & 2.29 & 0.97 & 5.40 & 0.058 \\
\hline \multirow[t]{2}{*}{$\begin{array}{r}\text { Prop. } ¥ \text { living in an other site for more than I month } \\
\text { during the preceding year }\end{array}$} & $<15 \%$ & 1920 & 685 & 36 & 1.00 & & & \\
\hline & $>=15 \%$ & 1132 & 577 & 51 & 2.24 & 0.92 & 5.45 & 0.077 \\
\hline \multirow{2}{*}{$\begin{array}{r}\text { Proportion of visitors among individuals present in } \\
\text { the households the night before }\end{array}$} & $<2 \%$ & 1918 & 635 & 33 & 1.00 & & & \\
\hline & $>=2 \%$ & 1134 & 627 & 55 & 3.02 & 1.29 & 7.07 & 0.011 \\
\hline \multirow[t]{2}{*}{ Prop. $\ddagger$ had a not damaged bed-net } & $<30 \%$ & 1826 & 868 & 48 & 1.00 & & & \\
\hline & $>=30 \%$ & 1226 & 394 & 32 & 0.48 & 0.20 & 1.15 & 0.100 \\
\hline \multirow[t]{2}{*}{$\begin{array}{r}\text { Prop. } \ddagger \text { had access to stockpiles of antimalarial drugs } \\
\text { at home }\end{array}$} & $<20 \%$ & 1955 & 605 & 31 & 1.00 & & & \\
\hline & $>=20 \%$ & 1097 & 657 & 60 & 4.05 & 1.86 & 8.81 & 0.000 \\
\hline \multirow[t]{3}{*}{ Average number of individuals by household } & $<7$ & 834 & 501 & 60 & 1.00 & & & \\
\hline & $7-9$ & 1293 & 504 & 39 & 0.35 & 0.13 & 0.93 & 0.035 \\
\hline & $>=10$ & 925 & 257 & 28 & 0.21 & 0.07 & 0.61 & 0.004 \\
\hline \multirow[t]{2}{*}{ Socioeconomic level score in 2 classes } & $<6$ & 2540 & 914 & 36 & 1.00 & & & \\
\hline & $>=6$ & 512 & 349 & 68 & 4.73 & 1.74 & 12.87 & 0.002 \\
\hline \multirow[t]{3}{*}{$\begin{array}{r}\text { Length of the travel to join the nearest sanitary } \\
\text { structure }\end{array}$} & $<1 \mathrm{~km}$ & 404 & 304 & 75 & 1.00 & & & \\
\hline & $\mathrm{I}-9.9 \mathrm{~km}$ & 1034 & 425 & 41 & 0.20 & 0.06 & 0.67 & 0.010 \\
\hline & $>=10 \mathrm{~km}$ & 1614 & 533 & 33 & 0.13 & 0.04 & 0.42 & 0.001 \\
\hline \multirow{3}{*}{$\begin{array}{r}\text { Length of the travel to join the pharmacy the most } \\
\text { used }\end{array}$} & $<5 \mathrm{~km}$ & 504 & 340 & 67 & 1.00 & & & \\
\hline & $5-9.9 \mathrm{~km}$ & 1034 & 425 & 41 & 0.29 & 0.09 & 0.95 & 0.041 \\
\hline & $>=10 \mathrm{~km}$ & 1514 & 497 & 33 & 0.19 & 0.06 & 0.57 & 0.003 \\
\hline \multirow[t]{2}{*}{$\begin{array}{r}\text { Duration of the route to join the nearest tarmacked } \\
\text { road }\end{array}$} & $<$ I hour & 1336 & 640 & 48 & 1.00 & & & \\
\hline & $>=1$ hour & 1716 & 622 & 36 & 0.56 & 0.23 & 1.37 & 0.206 \\
\hline \multirow{3}{*}{$\begin{array}{l}\text { Prevalence rate of the anti-CSP antibodies among } \\
\text { children between two and nine years of age }\end{array}$} & $<20 \%$ & 635 & 245 & 39 & 1.00 & & & \\
\hline & $20-39.9 \%$ & 1227 & 746 & 61 & 2.81 & 1.13 & 6.97 & 0.026 \\
\hline & $>=40 \%$ & 1190 & 271 & 23 & 0.44 & 0.17 & 1.12 & 0.088 \\
\hline \multirow{4}{*}{$\begin{array}{r}\text { Prevalence rate of } P \text {. falciparum trophozoites among } \\
\text { children between two and nine years of age }\end{array}$} & $<25 \%$ & 428 & 126 & 29 & 1.00 & & & \\
\hline & $25-49 \%$ & 526 & 351 & 67 & 6.62 & 1.67 & 26.23 & 0.007 \\
\hline & $50-74 \%$ & 989 & 407 & 41 & 1.76 & 0.52 & 5.92 & 0.359 \\
\hline & $>=75 \%$ & 1109 & 378 & 34 & 1.27 & 0.38 & 4.21 & 0.693 \\
\hline
\end{tabular}

$* N$ number of samples of urine, $\nmid \mathrm{CQ}+=$ number of samples with chloroquine in urines, $\ddagger$ Prop.: proportion of inhabitants of the site who Logistic regression model with random effect taking into account the interdependency of observations made within the same site.

prevalence of anti-CSP antibodies was used as a proxy of the level of intensity of malaria transmission. This level is usually measured by determining the entomological inoculation rate. Parasite prevalence can be used as an alternative proxy [31], but in the present study the prevalence of anti-CSP antibodies was preferred because it is not modified by antimalarial treatment [32] or parasite resistance to drugs. CSP is actively expressed only during the sporozoite stage and is generally used as a proxy of the level of exposure to malaria [33]. In the present study, the prevalence of CQ in children's urine was higher in sites where the prevalence of anti-CSP antibodies was intermediate (between 20 and 39.9\%). There are contrasting views on the role of transmission intensity of $P$. falciparum on drug consumption and spread of CQ resistance. In the study by Talisuna et al, conducted in seven sites in Uganda and involving 1,504 people aged 1-45 years, CQ use in all ages was inversely related to parasite prevalence [10]. The 
Table 5: Multivariate analysis of the presence of chloroquine in urines of children between two and nine years of age.

\begin{tabular}{|c|c|c|c|c|c|c|c|c|c|c|c|}
\hline \multirow{2}{*}{$\begin{array}{l}\text { Variables } \\
\text { Age }\end{array}$} & \multirow[t]{2}{*}{$\mathbf{N}$} & \multirow[t]{2}{*}{$\mathrm{CQ}^{+*}$} & \multirow[t]{2}{*}{ Prevalence of CQ $† \%$} & \multirow[t]{2}{*}{ Crude OR } & \multicolumn{2}{|c|}{$95 \% \mathrm{Cl}$} & \multirow[t]{2}{*}{ p $\ddagger$} & \multirow[t]{2}{*}{ Adjusted OR } & \multicolumn{2}{|c|}{$95 \% \mathrm{Cl}$} & \multirow[t]{2}{*}{$\mathbf{p} \ddagger$} \\
\hline & & & & & & & & & & & \\
\hline 2-5 years old & 1419 & 691 & 49 & 1.00 & & & & 1.00 & & & \\
\hline 6-9 years old & 1633 & 571 & 35 & 0.74 & 0.09 & 0.63 & 0.001 & 0.76 & 0.64 & 0.90 & 0.002 \\
\hline \multicolumn{12}{|c|}{$\begin{array}{l}\text { Fever during the preceding } \\
3 \text { days }\end{array}$} \\
\hline without & 2252 & 852 & 38 & 1.00 & & & & 1.00 & & & \\
\hline with & 800 & 410 & 51 & 1.24 & 1.02 & 1.50 & 0.032 & 1.22 & 1.01 & $\mathrm{I} .49$ & 0.043 \\
\hline \multicolumn{12}{|c|}{$\begin{array}{l}\text { Proportion of individuals } \\
\text { who were living in an other } \\
\text { locality one year before } \\
\text { the study }\end{array}$} \\
\hline$<5 \%$ & 1424 & 471 & 33 & 1.00 & & & & 1.00 & & & \\
\hline$>=5 \%$ & 1628 & 791 & 49 & 2.29 & 0.97 & 5.40 & 0.058 & 2.53 & 1.38 & 4.64 & 0.003 \\
\hline \multicolumn{12}{|c|}{$\begin{array}{l}\text { Score in } 2 \text { classes } \\
\text { representing the } \\
\text { households' average } \\
\text { socioeconomic level }\end{array}$} \\
\hline$<6$ & 2540 & 914 & 36 & 1.00 & & & & 1.00 & & & \\
\hline$>=6$ & 512 & 349 & 68 & 4.73 & 1.74 & 12.87 & 0.002 & 2.74 & I.II & 6.78 & 0.029 \\
\hline \multicolumn{12}{|c|}{$\begin{array}{l}\text { Prevalence rate of the anti- } \\
\text { CSP antibodies }\end{array}$} \\
\hline$<20 \%$ & 635 & 245 & 39 & 1.00 & & & & 1.00 & & & \\
\hline $20-39.9 \%$ & 1227 & 746 & 61 & 2.82 & 1.11 & 7.16 & 0.0289 & 2.47 & 1.13 & 5.41 & 0.023 \\
\hline$>=40 \%$ & 1190 & 271 & 23 & 0.44 & 0.17 & 1.12 & 0.0885 & 0.68 & 0.32 & 1.43 & 0.305 \\
\hline \multicolumn{12}{|c|}{$\begin{array}{l}\text { Duration of the route to } \\
\text { join the nearest tarmacked } \\
\text { road }\end{array}$} \\
\hline$<$ I hour & 1336 & 640 & 48 & 1.00 & & & & 1.00 & & & \\
\hline$>=1$ hour & 1716 & 622 & 36 & 0.56 & 0.23 & 1.37 & 0.206 & 0.49 & 0.27 & 0.89 & 0.019 \\
\hline
\end{tabular}

$* \mathrm{CQ}+=$ number of samples with chloroquine in urines, $\dagger \mathrm{CQ}$ : Chloroquine, $\ddagger \mathrm{p}$ : $\mathrm{p}$-value

Logistic regression model with random effect taking into account the interdependency of observations made within the same site.

authors attributed this association with parasite prevalence, i.e. malaria endemicity, to the more rapid acquisition of antimalarial immunity in areas where the exposure to malaria infection is higher. A limitation of this study was the use of the parasite prevalence as the indicator for transmission intensity: this variable could be biased by drug use and drug resistance. In the present study, intermediate prevalence rate of anti-CSP antibodies, i.e. intermediate level of transmission, was significantly associated with higher consumption of CQ. It is consistent with the observation of Trape and Rogier who have reported that the cumulated incidence of clinical malaria was higher in intermediate endemic areas [4].

In terms of the spread of CQ resistance, there are three conflicting hypotheses on the role of malaria transmission $[8,9]$. The first hypothesis suggests that low transmission level increases the rate of spread of resistance because resistance gene combinations would be more stable and hence spread faster $[34,35]$. The second suggests that resistant parasites spread faster when transmission is high if intra-host dynamics exist: the increasing transmission intensity can increase the number of co-infecting clones, and antimalarial drug use would eradicate the drug susceptible clones and allow the survival of the resistant clones [35]. The third hypothesis suggests that the intensity of transmission intensity plays no role in the early stages of the evolution of parasite resistance [36]. All of these hypotheses do not take into consideration the effect of drug use. The present study shows that drug selection pressure was different between sites with different levels of transmission intensity. This observation should be taken into account for modeling the spread of drug resistance in relation to malaria transmission and acquisition of clinical immunity.

\section{Diversity of antimalarial drug use}

Few drugs other than CQ were present in the urine samples analysed in the present study. The prevalence of pyrimethamine in urine ranged from 0 to $21 \%$ (median $0 \%)$, depending on the sites. This could at least partly explain the low level of antifolate resistance during the study. In the meta-analysis of Talusina et al, the median of the prevalence of sulphadoxine-pyrimethamine (SP) 
treatment failure in Africa between 1996 and 2002 varied from 0 to $35 \%$ [8]. The widespread adoption of intermittent preventive treatment using SP in pregnant women could lead to an increased prevalence of resistances to this drug in the next future. Since 2001 the World Health Organization recommends that treatment policies in all countries experiencing resistance of $P$. falciparum to conventional monotherapies should be combination therapies, preferably those containing artemisinin derivatives [37]. However, a change in national antimalarial treatment policies can take several years. In 2003, CQ was still the usual treatment in the three countries where the present study was conducted.

\section{Evaluating drug consumption}

To assess the level of antimalarial drug consumption, two methods can be used: questionnaires and biological methods for detecting drugs in urine or blood. The assessment of antimalarial drug consumption by questionnaires is less reliable than biological methods because of misunderstanding of questions, failed memory, or deliberate attemps to provide false information $[10,13,20]$. In the present study, drug consumption was assessed by a CQ- and PYR-specific dipstick. The urine dipstick detects the presence of CQ and PYR and, by cross-reaction, also detects amodiaquine and proguanil. However, the standard method to detect and measure antimalarial drugs in urine and blood is high-performance liquid chromatography (HPLC). Since the latter is more expensive than urine dipstick, it was not used for all samples in this study. Proguanil was not found in urine by HPLC, and amodiaquine was present in only $6 \%$ of the samples. Therefore, the analysis of antimalarial consumption seems not biased by cross reactions.

\section{Conclusion}

Antimalarial drug pressure considerably varied from one site to another, including within the same region, and was significantly higher in areas with intermediate malaria transmission level, i.e. where the level of acquired malaria immunity is intermediate, and in the most accessible sites. Therefore, incoming resistant $P$ falciparum strains from other sites would find favourable conditions to become established and spread in the receiving human population.

\section{Authors' contributions}

FG performed the statistical analysis and wrote the article. FS, HB and MB took part in the analyze of the data and the discussion about the results. SA did the immunological analysis. Dipsticks were designed by TE. FB, VF, LB, JFT PTK and $\mathrm{MCH}$ participated in the collection of data. MM and MD carried out the high-performance liquid chromatography. SB, TF, LA and BP participated in the discussion of the results. RL took part in the elaboration of the ques-

tionnaires. CR conceived the study, took part in the analyze of the data and the discussion and wrote the article. The final version of the manuscript was seen and approved by all authors.

\section{Additional material}

\section{Additional File 1 \\ Individuals and households' characteristics by site. Click here for file \\ [http://www.biomedcentral.com/content/supplementary/1475- 2875-7-124-S1.xls]}

\section{Additional File 2}

Sites characteristics.

Click here for file

[http://www.biomedcentral.com/content/supplementary/14752875-7-124-S2.xls]

\section{Additional File 3}

Children's characteristics.

Click here for file

[http://www.biomedcentral.com/content/supplementary/14752875-7-124-S3.xls]

\section{Additional File 4}

Chloroquine prevalence in urines of children between two and nine years of age according to site's characteristics.

Click here for file

[http://www.biomedcentral.com/content/supplementary/1475-

2875-7-124-S4.xls]

\section{Additional File 5}

Predicted and observed prevalence by site of the presence of chloroquine in children's urines.

Click here for file

[http://www.biomedcentral.com/content/supplementary/14752875-7-124-S5.doc]

\section{Acknowledgements}

This study was funded by the PAL+ Programme of the French Ministry for Research and Delegation Generale pour l'Armement (DGA, contract 03c0007-05).

We are grateful to Michel De Pauw, Pr Robert Guiguemde, all the nurses, physicians, technicians, field workers and villagers who participated or assisted in the collection data. We are grateful to Dr Claire Dane from DGA for her constant support.

\section{References}

I. WHO: The world health report : shaping the future. WHO; 2003.

2. Trape JF: The public health impact of chloroquine resistance in Africa. Am J Trop Med Hyg 200I, 64(I-2 Suppl): I2-17.

3. Trape JF, Pison G, Spiegel A, Enel C, Rogier C: Combating malaria in Africa. Trends Parasitol 2002, 18(5):224-230.

4. Trape JF, Rogier C: Combating malaria morbidity and mortality by reducing transmission. Parasitol Today 1996, I 2(6):236-240. 
5. Bhattarai A, Ali AS, Kachur SP, Martensson A, Abbas AK, Khatib R, Al-Mafazy AW, Ramsan M, Rotllant G, Gerstenmaier JF, Molteni $F$ Abdulla S, Montgomery SM, Kaneko A, Bjorkman A: Impact of artemisinin-based combination therapy and insecticidetreated nets on malaria burden in Zanzibar. PLOS Med 2007, 4(I I):e309.

6. Owusu-Agyei S, Awini E, Anto F, Mensah-Afful T, Adjuik M, Hodgson $A$, Afari E, Binka F: Assessing malaria control in the KassenaNankana district of northern Ghana through repeated surveys using the RBM tools. Malar J 2007, 6: 103 .

7. Nyarango PM, Gebremeskel T, Mebrahtu G, Mufunda J, Abdulmumini U, Ogbamariam A, Kosia A, Gebremichael A, Gunawardena D, Ghebrat $Y$, Okbaldet $Y$ : A steep decline of malaria morbidity and mortality trends in Eritrea between 2000 and 2004: the effect of combination of control methods. Malar J 2006, 5:33.

8. Talisuna AO, Bloland P, D'Alessandro U: History, dynamics, and public health importance of malaria parasite resistance. Clin Microbiol Rev 2004, I 7(I):235-254.

9. Talisuna AO, Erhart A, Samarasinghe S, Van Overmeir C, Speybroeck $\mathrm{N}, \mathrm{D}$ 'Alessandro U: Malaria transmission intensity and the rate of spread of chloroquine resistant Plasmodium falciparum: Why have theoretical models generated conflicting results? Infect Genet Evol 2006, 6(3):24I-248.

10. Talisuna AO, Langi P, Bakyaita N, Egwang T, Mutabingwa TK, Watkins W, Van Marck E, D'Alessandro U: Intensity of malaria transmission, antimalarial-drug use and resistance in Uganda: what is the relationship between these three factors? Trans $R$ Soc Trop Med Hyg 2002, 96(3):310-317.

II. Roll back Malaria: Global Strategic Plan 2005-20I5 . 2005.

12. Williams HA, Jones CO: A critical review of behavioral issues related to malaria control in sub-Saharan Africa: what contributions have social scientists made? Soc Sci Med 2004 59(3):50I-523.

13. Verhoef $\mathrm{H}$, Hodgins E, Eggelte TA, Carter JY, Lema O, West CE, Kok $\mathrm{FJ}$ : Anti-malarial drug use among preschool children in an area of seasonal malaria transmission in Kenya. Am J Trop Med Hyg 1999, 6 I (5):770-775.

14. Schwick P, Eggelte TA, Hess F, Tueumuna TT, Payne D, Nothdurft $H D$, von Sonnenburg F, Loscher T: Sensitive ELISA dipstick test for the detection of chloroquine in urine under field conditions. Trop Med Int Health 1998, 3(10):828-832.

15. Basco LK, Ndounga M, Keundjian A, Ringwald P: Molecular epidemiology of malaria in cameroon. IX. Characteristics of recrudescent and persistent Plasmodium falciparum infections after chloroquine or amodiaquine treatment in children. Am J Trop Med Hyg 2002, 66(2): I 17- 123.

16. Benakis A, Binh TQ, Keundjian A, Scheiwe MW: Pharmacokinetics/Pharmacodynamics findings after repeated administration of ARTESUNATE thermostable suppositories (RECTOCAPS) in Vietnamese patients with uncomplicated malaria. Eur J Drug Metab Pharmacokinet 2006, 3 I(I):4I-45.

17. Sharma M, Ghosh S, Singal AK, Anand BS, Talwar GP: Use of micro samples of finger prick blood dried on filter paper for a quick and simple dipstick dot-EIA for diagnosis of amebic liver abscess (ALA). J Clin Lab Anal 1994, 8(2):96-98.

18. Orlandi-Pradines E, Penhoat K, Durand C, Pons C, Bay C, Pradines B, Fusai T, Josse R, Dubrous P, Meynard JB, Durand JP, Migliani R, Boutin $J P$, Druilhe $P$, Rogier C: Antibody responses to several malaria pre-erythrocytic antigens as a marker of malaria exposure among travelers. Am J Trop Med Hyg 2006, 74(6):979-985.

19. http://www.epiconcept.fr/html/epidata.html: .

20. Mockenhaupt FP, May J, Bergqvist $Y$, Ademowo OG, Olumese PE, Falusi AG, Grossterlinden L, Meyer CG, Bienzle U: Concentrations of chloroquine and malaria parasites in blood in Nigerian children. Antimicrob Agents Chemother 2000, 44(4):835-839.

21. Hellgren U, Ericsson O, Kihamia CM, Rombo L: Malaria parasites and chloroquine concentrations in Tanzanian schoolchildren. Trop Med Parasitol 1994, 45(4):293-297.

22. Muller O, Traore C, Becher H, Kouyate B: Malaria morbidity, treatment-seeking behaviour, and mortality in a cohort of young children in rural Burkina Faso. Trop Med Int Health 2003, 8(4):290-296.

23. Guyatt HL, Snow RW: The management of fevers in Kenyan children and adults in an area of seasonal malaria transmission. Trans R Soc Trop Med Hyg 2004, 98(2): I I I-II5.
24. Nshakira N, Kristensen M, Ssali F, Whyte SR: Appropriate treatment of malaria? Use of antimalarial drugs for children's fevers in district medical units, drug shops and homes in eastern Uganda. Trop Med Int Health 2002, 7(4):309-3I6.

25. Baird JK: Host age as a determinant of naturally acquired immunity to Plasmodium falciparum. Parasitol Today 1995 , I I(3): I05-III.

26. Aponte JJ, Menendez C, Schellenberg D, Kahigwa E, Mshinda H, Vountasou P, Tanner M, Alonso PL: Age interactions in the development of naturally acquired immunity to Plasmodium falciparum and its clinical presentation. PLoS Med 2007, 4(7):e242.

27. Biritwum RB, Welbeck J, Barnish G: Incidence and management of malaria in two communities of different socio-economic level, in Accra, Ghana. Ann Trop Med Parasitol 2000, 94(8):77|-778.

28. Kazembe LN, Appleton CC, Kleinschmidt I: Choice of treatment for fever at household level in Malawi: examining spatial patterns. Malar J 2007, 6:40.

29. Uzochukwu BS, Onwujekwe OE: Socio-economic differences and health seeking behaviour for the diagnosis and treatment of malaria: a case study of four local government areas operating the Bamako initiative programme in south-east Nigeria. Int J Equity Health 2004, 3(I):6.

30. Charmot G, Rodhain F: [Drug resistance of Plasmodium falciparum. Analysis of factors in its appearance and spread]. Med Trop (Mars) 1982, 42(4):417-426

31. Snow RW, Omumbo JA, Lowe B, Molyneux CS, Obiero JO, Palmer A, Weber MW, Pinder M, Nahlen B, Obonyo C, Newbold C, Gupta $S$, Marsh K: Relation between severe malaria morbidity in children and level of Plasmodium falciparum transmission in Africa. Lancet 1997, 349(9066):1650-1654.

32. Philpott J, Keystone JS, Reid A, Chulay JD, Wirtz RA, Szarfman A: Effect of malaria chemoprophylaxis on the development of antibodies to Plasmodium falciparum in expatriates living in west Africa. Am J Trop Med Hyg 1990, 42(I):28-35.

33. Druilhe P, Pradier O, Marc JP, Miltgen F, Mazier D, Parent G: Levels of antibodies to Plasmodium falciparum sporozoite surface antigens reflect malaria transmission rates and are persistent in the absence of reinfection. Infect Immun 1986, 53(2):393-397.

34. White NJ: Antimalarial drug resistance. J Clin Invest 2004, I I3(8): 1084-1092.

35. Hastings IM: Malaria control and the evolution of drug resistance: an intriguing link. Trends Parasitol 2003, 19(2):70-73.

36. Hastings IM, Watkins WM: Intensity of malaria transmission and the evolution of drug resistance. Acta Trop 2005, 94(3):2 I 8-229.

37. WHO: Guidelines for the treatment of malaria. WHO/HTM/ MAL/:I 108; 2006

\section{Publish with Bio Med Central and every scientist can read your work free of charge}

"BioMed Central will be the most significant development for disseminating the results of biomedical research in our lifetime. "

Sir Paul Nurse, Cancer Research UK

Your research papers will be:

- available free of charge to the entire biomedical community

- peer reviewed and published immediately upon acceptance

- cited in PubMed and archived on PubMed Central

- yours - you keep the copyright
BioMedcentral 